\title{
Identification and analysis of the Saccharomyces cerevisiae SYR1 gene reveals that ergosterol is involved in the action of syringomycin
}

\author{
Nobuhisa Taguchi, ${ }^{1}$ Yoshihiko Takano, ${ }^{1}$ Charnchai Julmanop, ${ }^{1}$ \\ Yeelan Wang, ${ }^{2}$ Steve Stock, ${ }^{2}$ Jon Takemoto ${ }^{2}$ and Tokichi Miyakawa ${ }^{1}$
}

Author for correspondence: Tokichi Miyakawa. Tel: +81824 22 7196. Fax: +81 824227191.

1 Department of

Fermentation Technology,

Faculty of Engineering,

Hiroshima University,

Higashi-Hiroshima 724,

Japan

2 Department of Biology, Utah State University, Logan, Utah 84322-5305, USA

\begin{abstract}
A 2.5 kb DNA fragment of the Saccharomyces cerevisiae SYR1 gene was cloned by complementation of the syr1 mutations that simultaneously lead to resistance to the phytotoxin syringomycin and sensitivity of growth to high $\mathrm{Ca}^{2+}$ concentrations. Sequencing of this fragment revealed a single open reading frame encoding a polypeptide of $\mathbf{3 6 5}$ amino acids. Four hydrophobic regions each separated by hydrophilic regions were present in the protein. SYR1 was identical to ERG3, which is suggested to encode C-5 sterol desaturase required for ergosterol biosynthesis. The protein product of SYR1 was identified by Western blot analysis as a protein of $40 \mathrm{kDa}$ in the particulate fraction. Gene disruption experiments demonstrated that elimination of SYR1/ERG3 is not lethal, but results in membrane C-5 desaturated sterol deficiencies, resistance to syringomycin and sensitivity to high $\mathrm{Ca}^{2+}$. The syr1 mutant cells had significantly decreased ability for syringomycin binding. The results indicated that C-5 desaturated sterols are involved in the binding of syringomycin to the cell, and the lack of the sterols in the mutant membrane results in sensitivity to high $\mathrm{Ca}^{2+}$ and an increased rate of cellular $\mathrm{Ca}^{2+}$ influx.
\end{abstract}

Keywords: Saccharomyces cerevisiae, ergosterol, syringomycin, SYR1

\section{INTRODUCTION}

The phytotoxin syringomycin is a major virulence factor produced by many strains of the bacterial plant pathogen Pseudomonas syringae pv. syringae (De Vay et al., 1968; Sinden et al., 1971). Syringomycin is a lipodepsipeptide with a molecular mass of $1226 \mathrm{Da}$ (Segre et al., 1989; Fukuchi et al., 1990). In addition to contributing to plant disease, syringomycin inhibits the growth of several fungi including the yeast Saccharomyces cerevisiae (Zhang \& Takemoto, 1986, 1987; Takemoto et al., 1991). Plants and yeast appear to respond similarly to syringomycin, and the effects suggest action on membrane components. The host plasma membrane appears to be the primary site of syringomycin action. The effects on this membrane include increases in $\mathrm{K}^{+}$efflux, $\mathrm{Ca}^{2+}$ influx and membrane potential, and protein phosphorylation (Bidwai \& Takemoto, 1987; Takemoto et al., 1991).

To elucidate the mechanism of syringomycin action, a molecular genetic approach using syringomycin-resistant mutants of $S$. cerevisiae was undertaken (Takemoto et al.,
1991). About $25 \%$ of the mutants (comprising at least 12 gene complementation groups) exhibited increased sensitivity of growth to $\mathrm{Ca}^{2+}$ in the medium and higher rates of $\mathrm{Ca}^{2+}$ transport. A single recessive mutation is responsible for both the resistance to syringomycin and for the sensitivity of growth to high $\mathrm{Ca}^{2+}$ concentrations (Takemoto et al., 1991).

In the present study, we cloned the gene SYR 1 (syringomycin resistant) that complements the phenotypes of the syringomycin-resistant mutants R4-3G and $3 \mathrm{~N}-\mathrm{H} 1$ (syr1-1 and syr 1-2, respectively). The cloned gene was identical with ERG3, which is suggested to be involved in the synthesis of membrane ergosterol (Arthington et al., 1991). The relationship between the phenotypes of syr 1 and the alteration in membrane sterol is demonstrated.

\section{METHODS}

Strains, media and general recombinant DNA methods. The Syringomycin-resistant mutant $S$. cerevisiae R4-3G (syr1-1), isolated from the wild-type haploid $8 \mathrm{~A}-1 \mathrm{~B}(M A T \mathbf{a} p h o 3$ bis 3 
leu2), was described previously (Takemoto et al., 1991). The mutant was crossed with KZ1-1D (MAT $\alpha$ ura 3 trp1 bis 3 leu2) to obtain a mutant R4-3G-12B with desired auxotrophic markers (MATa syr1 ura 3 trp1 bis3 leu2). Strain 3N-H1 (syr1-2) showing a similar phenotype to $\mathrm{R} 4-3 \mathrm{G}$ was isolated from strain $\mathrm{KZ} 1-1 \mathrm{C}$ (MATa ura3 trp1 bis3 leu2). The two syringomycin-resistant mutants belong to the same genetic complementation group. Bacterial strains and yeast plasmid vectors were as described previously (Liu et al., 1991). Genomic libraries of S. cerevisiae made in Escherichia coli using the centromere vectors YCpN1, YCp50 and the multicopy vector YEp24 were used. Standard yeast media, YPD, SD and $\mathrm{LB}$, and tetrad analysis were as described previously (Liu et al., 1991). Syringomycin was added to YPD agar at a concentration of $2 \mu \mathrm{g} \mathrm{ml}^{-1}$. Solutions of syringomycin and $\mathrm{CaCl}_{2}$ were sterilized separately and added to YPD medium at temperatures below $60^{\circ} \mathrm{C}$. Transformation was done according to the method of Ito $e t$ al. (1983).

Nucleotide sequence determination. DNA sequencing was performed using the dideoxynucleotide chain-termination method with M13mp18 or M13mp19 (Sanger et al., 1977). Suitable clones for sequencing were produced using various restriction enzymes. DNA sequences were determined on both strands.

Disruption of SYR1. Plasmid pNT1 was constructed by inserting the $2.5 \mathrm{~kb} X b o \mathrm{I}-B a m \mathrm{HI}$ fragment of $S Y \mathrm{R} 1$ into M13mp18. Plasmid pNT2 was constructed by replacing the SalI-ScaI fragment of pNT1 with the SalI-SmaI fragment of the HIS3 gene. The diploid S. cerevisiae strain RAY-3A-D (Tanaka et al., 1989) was transformed with pNT2 linearized with PvuII. The one-step gene disruption method was used (Rothstein, 1983).

Preparation of fusion protein and specific antibody. For the preparation of SYR 1 fusion protein, the bacterial expression vector pEX3 was used. The SspI-HpaI fragment within the open reading frame (ORF) was inserted at the $S m a$ I site of the expression vector $\mathrm{pEX} 3$ to produce the cro-lac $Z-S Y \mathrm{R} 1$ gene fusion. Upon heat induction, the resulting plasmid, pNTF1, produced in E. coli strain pop2136 a large amount of polypeptide of about $140 \mathrm{kDa}$, consistent with the size of the predicted fusion protein. The fusion protein was purified by slab preparative SDS-PAGE. After staining the gel with Coomassie blue, the fusion protein band was excised from the gel, eluted from the gel electrophoretically and dialysed against water. Mouse antisera were prepared by first immunizing mice with $50 \mu \mathrm{g}$ protein in complete adjuvant, and then five times with $20 \mu \mathrm{g}$ protein in incomplete adjuvant with an interval of $10 \mathrm{~d}$ between injections. Antibody was purified on an affinity column of fusion protein bound to $\mathrm{CNBr}$-activated Sepharose 4B. Antibody against $\beta$-galactosidase in the eluate was further eliminated by passing through a $\beta$-galactosidase-Sepharose $4 \mathrm{~B}$ affinity column.

Protein electrophoresis and Western blot analysis. Yeast cells were grown to late-exponential-phase in $10 \mathrm{ml}$ YPD medium. The cells were harvested and washed twice with $1 \mathrm{ml}$ buffer 1 $(50 \mathrm{mM}$ imidazole $/ \mathrm{HCl}, \mathrm{pH} 7 \cdot 0,1 \mathrm{mM}$ 2-mercaptoethanol, $2 \mathrm{mM}$ EDTA, $1 \mathrm{mM}$ PMSF, $10 \mu \mathrm{g} \mathrm{ml}^{-1}$ each of leupeptin and pepstatin). Cell extracts were prepared by vortexing the cell pellet with glass beads $(0.45 \mathrm{~mm}$; Braun) in a microcentrifuge tube. After removing the glass beads, the lysate was centrifuged at 12000 r.p.m. for $15 \mathrm{~min}$ at $4{ }^{\circ} \mathrm{C}$. Equal amounts $(40 \mu \mathrm{g})$ of protein samples (supernatant and particulate fractions) were analysed by SDS-PAGE. After electrophoresis, the proteins were transferred onto a Biodyne membrane, and Syr1 protein was identified by Western blotting using antisera against Syr 1 . Protein samples were not heat treated in sample buffer for solubilization, as the treatment caused loss of Syr1 protein due to aggregation.

Extraction of nonsaponifiable lipids. The procedure for sterol extraction from yeast was that described by Woods (1971), using cells grown for $48 \mathrm{~h}$ at $28^{\circ} \mathrm{C}$ in YPD medium.

Binding assay for syringomycin. Syringomycin $(40 \mu \mathrm{g})$ was added to $S$. cerevisiae cells $\left(2 \times 10^{7}\right)$ suspended in $200 \mu \mathrm{l}$ YPD medium in a microcentrifuge tube. After incubation at $28{ }^{\circ} \mathrm{C}$ for various periods of time $(0-60 \mathrm{~min})$, the suspension was clarified by centrifugation for $1 \mathrm{~min}$ at $10000 \mathrm{~g}$. A $50 \mu \mathrm{l} \mathrm{sample} \mathrm{was} \mathrm{taken}$ from the supernatant fluid, and the amount of syringomycin was determined semi-quantitatively by measuring the growth inhibitory effect of the toxin using wild-type $S$. cerevisiae as assay cells.

Syringomycin purification. Syringomycin (E form) was purified as described previously (Bidwai \& Takemoto, 1987).

\section{RESULTS}

\section{SYR1 complements $\mathrm{Ca}^{2+}$ sensitivity of syringomycin- resistant mutants}

Syringomycin-resistant mutants R4-3G and $3 \mathrm{~N}-\mathrm{H} 1$ were previously selected from the wild-type strains $8 \mathrm{~A}-1 \mathrm{~B}$ and KZ1-1C, respectively, on the basis of their ability to grow on YPD agar containing $2 \mu \mathrm{g}$ syringomycin $\mathrm{ml}^{-1}$. The growth of R4-3G and $3 \mathrm{~N}-\mathrm{H} 1$ was inhibited by $0.4 \mathrm{M}$ and $0 \cdot 2 \mathrm{M} \mathrm{CaCl}_{2}$, respectively. The respective wild-type parental strains were able to grow with these levels of $\mathrm{Ca}^{2+}$. Both mutants showed increased rates of ${ }^{45} \mathrm{Ca}^{2+}$ uptake from the medium (Takemoto et al., 1991). Genetic analyses of these mutants showed single recessive mutations that simultaneously led to $\mathrm{Ca}^{2+}$-sensitive growth and syringomycin resistance (Takemoto et al., 1991). The two mutations, designated syr 1-1 and syr1-2, belonged to the same complementation group. For cloning of the genes that complement the syr1 phenotypes, we used genomic libraries of $S$. cerevisiae made with a centromere vector ( $\mathrm{YCpN} 1$ or $\mathrm{YCp} 50)$ and the multi-copy vector YEp24. Since R4-3G did not have appropriate auxotrophic markers for selection of these plasmids, strain R4-3G-12B (MAT $\alpha$ syr1-1 ura3 trp1 bis3 leu2) was obtained by crossing R4-3G with KZ1-1D. After transformation of R4-3G-12B and $3 \mathrm{~N}-\mathrm{H} 1$ with the genomic libraries, transformants were tested for the phenotypes to verify that the increased resistance to $\mathrm{Ca}^{2+}$ was due to the presence of the plasmid. The plasmids were then purified, amplified in E. coli, and used to transform the mutants to verify that the plasmids complemented $\mathrm{Ca}^{2+}$-sensitive growth.

About 5000 and 9000 transformants of R4-3G-12B were obtained using the YCpN1- and YEp24-based libraries, respectively. From these transformants, one (clone 22) YCpN1 - and four (clones 1, 3, 273 and 225) YEp24-based syr1-complementing clones were obtained. From about 3000 YCp50-library transformants of $3 \mathrm{~N}-\mathrm{H} 1$, five complementing clones were isolated (clones 28, 29, 32, 37 and $35)$. Restriction enzyme analysis of these clones suggested that they all contained a common DNA fragment found in the shortest clone, clone 1 . The restriction maps of some of these clones are shown in Fig. 1. Southern blot analyses of genomic DNA digested with various restriction 
Clone 22

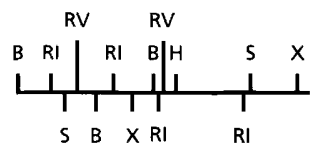

Clone 1

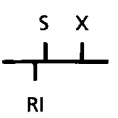

Clone 3

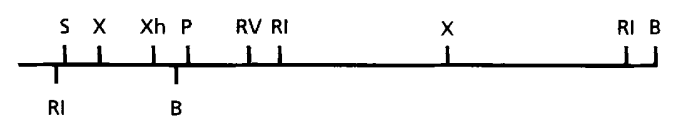

Clone 273

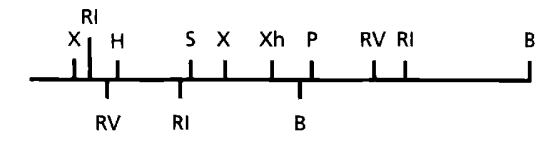

Fig. 1. Restriction maps of the genomic clones that complement $\mathrm{Ca}^{2+}$ sensitivity of syr1. Abbreviations for restriction sites are as follows: B, BamHI; RI, EcoRI; RV, EcoRV; $\mathrm{H}$, HindIII; P, Pstl; S, Sall; X, Xbal; Xh, Xhol.

$\begin{array}{llllll}B & P & \text { RI } & \text { H } & \text { RV }\end{array}$

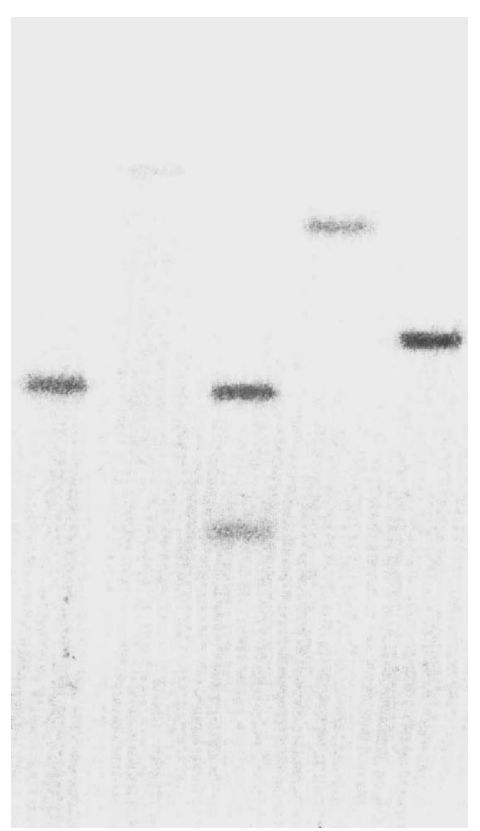

Fig. 2. Southern blot analysis of genomic SYR1. Genomic yeast DNA from RAY-3D-A $(10 \mu \mathrm{g})$ was digested with various restriction enzymes and used for hybridization with a labelled Xhol-Hindlll fragment of SYRI as probe. Hybridization was at $42{ }^{\circ} \mathrm{C}$. Abbreviations for restriction enzymes are the same as used in Fig. 1.

enzymes were carried out to determine if $S Y R 1$ is a singlecopy gene. One fragment with the expected size was produced with four restriction enzymes that did not cleave the SYR 1 gene, and two fragments were detected with EcoRI, for which a single restriction site was predicted by the cloned gene (Fig. 2). These results indicate that $S Y R 1$ is a single-copy gene. Chromosome IV was identified as the chromosome containing SYR 1 by Southern blot analysis of the chromosome separated by CHEF gel electrophoresis (data not shown).

\section{The SYR1 gene encodes C-5 sterol desaturase}

The $1.2 \mathrm{~kb}$ insert of clone 1 was sequenced. A sequence presumed to be part of an ORF was found, but a stop codon was missing at the $\mathrm{C}$-terminus. Thus, the nucleotide sequence of the $2 \cdot 5 \mathrm{~kb}$ XhoI-Bam HI fragment of clone 273 was determined (Fig. 1). In this fragment, an ORF of 1095 nucleotides that could encode a 365 -amino-acid protein $(42 \cdot 7 \mathrm{kDa})$ was found (data not shown). The sequence of clone 1 corresponded to amino acid residues $1-322$ of the ORF, indicating that the C-terminal 43 amino acids of the Syr1 protein are not essential for restoring $\mathrm{Ca}^{2+}$ sensitivity of syr 1 . The hydrophobicity profile of the predicted SYR 1 gene product revealed several hydrophobic domains sufficient in length to span a membrane, suggesting that the SYR1 gene product is a membrane protein. Comparison of the $S Y R 1$ sequence with those in the sequence databases showed that $S Y R 1$ is identical to yeast ERG3, a gene suggested to encode $\mathrm{C}-5$ sterol desaturase required for ergosterol biosynthesis (Arthington et al., 1991).

\section{The SYR1 gene is not essential for growth, and its disruption causes syringomycin resistance and $\mathrm{Ca}^{2+}$ sensitivity}

To investigate the relationship between the Syr1 protein and syringomycin resistance, SYR 1 was inactivated by the one-step gene disruption technique (Rothstein, 1983). The XboI-BamHI fragment of plasmid pNT2 was constructed by replacing a $300 \mathrm{bp}$ Sall-ScaI region within the ORF with the SalI-SmaI fragment of HIS3 (Fig. 3). The diploid S. cervisiae strain RAY-3A-D was transformed with pN'T2 linearized with PvuII. Gene disruption was confirmed by Southern hybridization (Fig. 3). Tetrad analysis of the diploid was carried out upon sporulation. Viable spores were scored for genotype according to their auxotrophic requirements, and 1:1 segregation patterns of syr1-A1 and SYR1 alleles were observed. Consistent with the results of ERG3 disruption (Arthington et al., 1991), all four spores were able to grow on YPD, showing that SYR 1 is not essential for mitotic growth. However, SYR1 disruptants $\left(\mathrm{His}^{+}\right.$colonies) were all resistant to syringomycin, and sensitive to $\mathrm{Ca}^{2+}$ (Fig. 4). Cells with 


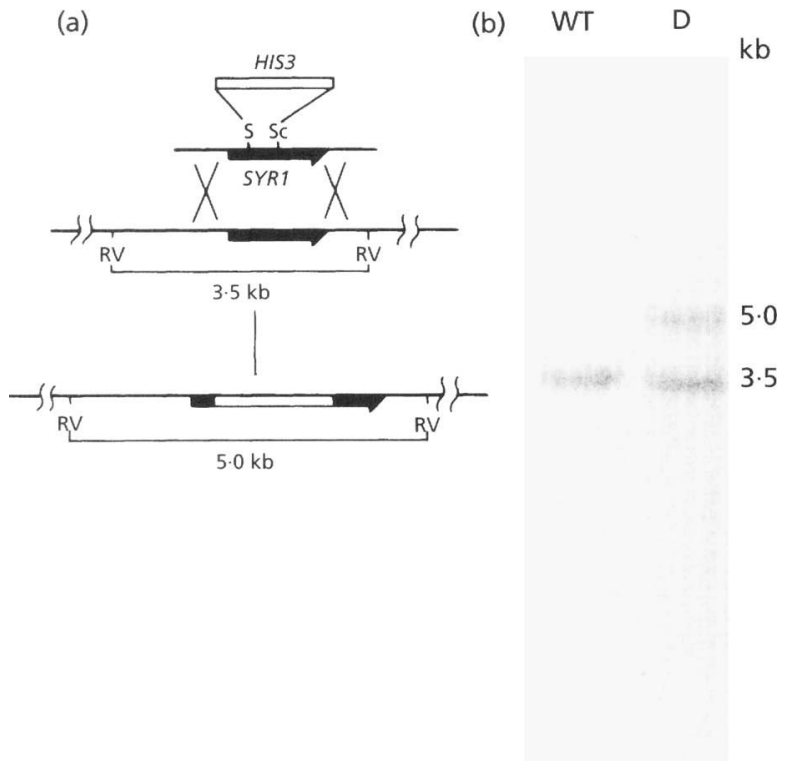

Fig. 3. (a) Disruption of SYR1. This was done as described in Methods. (b) Confirmation of gene disruption by Southern hybridization. Genomic yeast DNA $(10 \mu \mathrm{g})$ was digested with EcoRV and prepared for hybridization. The probe was the same as that used in experiments shown in Fig. 2. Lanes: WT, DNA from RAY-3D-A; D, DNA from His ${ }^{+}$transformed diploid (YT1). (a)

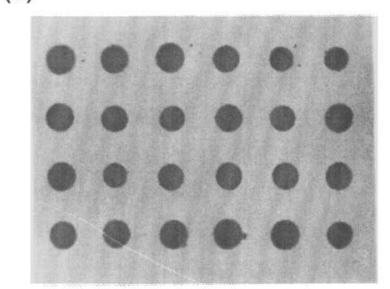

(c)

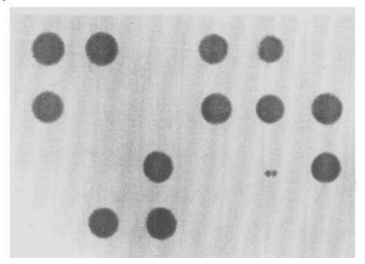

(b)

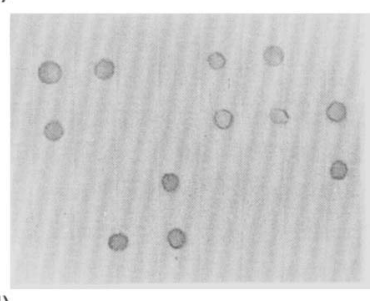

(d)

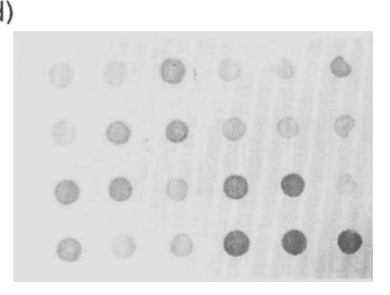

Fig. 4. Phenotypes of the syr1::HIS3 (syr1- $\Delta 1)$ disrupted meiotic segregant. Tetrad analysis of the syr1- $\triangle 1 / S Y R 1$ diploid (YT1) was performed. Growth of selected tetrads were tested on (a) YPD medium, (b) SD without histidine, (c) YPD medium containing $2 \mu \mathrm{g}$ syringomycin $\mathrm{ml}^{-1}$ and (d) YPD containing $400 \mathrm{mM} \mathrm{Ca}^{2+}$.

the disrupted allele had an elevated rate of $\mathrm{Ca}^{2+}$ uptake, as previously observed with syr $1-1$ mutants (Takemoto et al., 1991). When the syr1- $\Delta 1$ segregant was transformed with the YCpN1 plasmid bearing $S Y R 1$, both $\mathrm{Ca}^{2+}$-sensitive and syringomycin-resistant phenotypes were restored to wild-type levels. These results indicate that the function

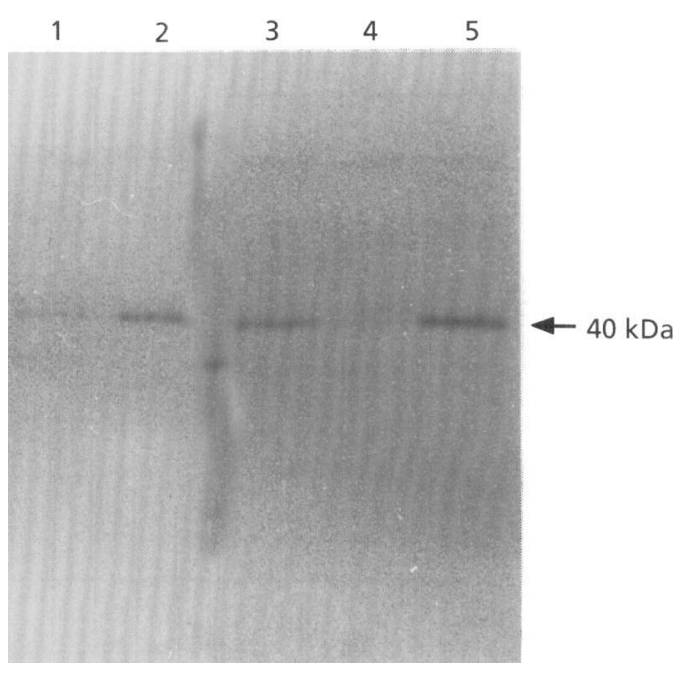

Fig. 5. Western blot analysis of the Syr 1 protein. Equal amounts of proteins $(30 \mu \mathrm{g})$ were separated by electrophoresis in a $10 \%$ (w/v) polyacrylamide gel in the presence of SDS and analysed by Western blotting as described above. Total cell lysates prepared from wild-type cells of YT1-1a (lane 1) and YT1-1a harbouring SYR1 on the YEp24 plasmid (lane 2) were immunoblotted with affinity-purified antibody against Syr 1 . Total cell extract (lane 3) prepared from YT1-1a harbouring SYR1 was fractionated to soluble (lane 4) and particulate (lane 5) fractions, as described in Methods, and analysed by Western blotting. No bands were formed when total cell lysates were immunoblotted with control serum.

of SYR1 is involved in both the action of syringomycin and in $\mathrm{Ca}^{2+}$ resistance of the cell.

\section{Identification of Syr1 protein}

For immunological detection of the SYR 1 product, Syr1, antiserum against LacZ-Syr1 fusion protein was prepared. Western blot analysis of whole-cell extracts prepared from a strain overexpressing $S Y R 1$ from a multicopy-number plasmid vector showed an immunoreactive polypeptide with a molecular mass of $40 \mathrm{kDa}$, corresponding in size to that expected from the deduced amino acid sequence $(42 \cdot 7 \mathrm{kDa})$. An increase in the intensity of this band was observed when $S Y R 1$ was overexpressed from a YEp24 multi-copy-number plasmid, but only a very weak band was seen in wild-type cells (Fig. 5), implying that SyrI is a minor protein of the cell. Syr1 was found in the particulate fraction, suggesting that it is bound to the membrane.

\section{syr1 mutants have altered membrane sterols}

Since SYR 1 encodes C-5 sterol desaturase, we measured the UV spectra of the nonsaponifiable lipid extracts to see if the levels of membrane ergosterol are altered in the syr 1 mutants (Fig. 6). Two of the sterols most abundant in S. cerevisiae, ergosterol and 24(28)-dehydroergosterol, are readily identified by their UV absorption spectra, but the other sterols present in the yeast membranes are not detectable from the absorption spectra (Breivik \& Owades, 1957). The lipid extract prepared from YT1-a, a SYR1 segregant of the diploid YT1 heterozygous at the 


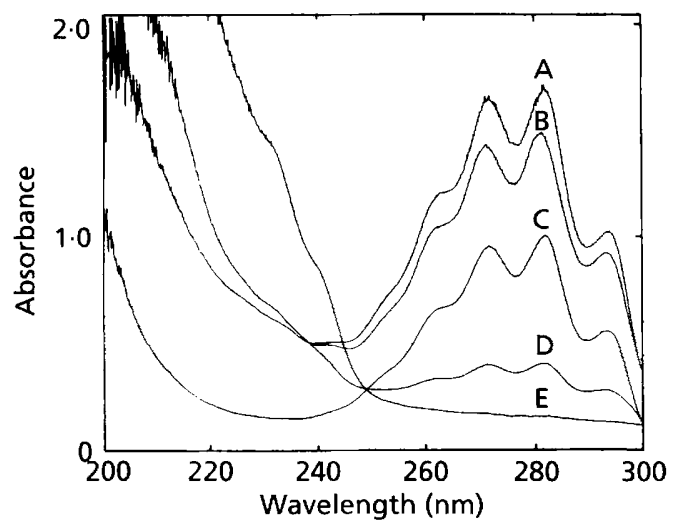

Fig. 6. UV absorption spectra of the nonsaponifiable lipid extracts from $S$. cerevisiae strains YT1-1a (SYR1) (A), YT1-1b harbouring YCpN1 (SYR1) (B), R4-3G (D) and YT1-1b (syr1- $\Delta 1$ ) (E). Ergosterol $\left(20 \mu \mathrm{g} \mathrm{ml}^{-1}\right)$ in heptane/ethanol $(1: 9, \mathrm{v} / \mathrm{v})$ is also shown (C).

SYR1 locus, showed that this strain contains ergosterol and possibly 24(28)-dehydroergosterol as the major UVabsorbing materials, as described by Bard (1972). In contrast, a syr1- $\Delta 1$ segregant (YT1-b) did not contain detectable amounts of UV-absorbing materials in the corresponding fraction, suggesting that ergosterol is not essential for the growth of yeast cells (Fig. 6). This result is consistent with the data of Arthington et al. (1991), which demonstrated the lack of C-5-desaturated sterols in the mutant strains by GC-MS analysis. When SYR 1 was introduced into syr1- 11 mutant cells using YCp or YEp vectors, the level of ergosterol was restored close to the wild-type level. The cells of $s y r-1-1$ had a very low level (less than $10 \%$ of that in wild-type cells) of the UVabsorbing substances (Fig. 6).

\section{syr1 mutants have decreased ability for syringomycin binding}

Syringomycin presumably binds to the surface of sensitive cells as the first step of its action. To measure the syringomycin-binding ability of the cells, cell samples were incubated with syringomycin in YPD medium, and the amount of syringomycin remaining in the medium was measured. Cells were pelleted by centrifugation at various periods of incubation, and toxin concentration in the clarified supernatant fluid was determined semiquantitatively by bioassay using sensitive $S$. cerevisiae as indicator (Fig. 7). With wild-type cells, the amount of toxin in the supernatant rapidly decreased. In contrast, the toxin level did not appreciably decrease with syr $1-41$ cells, suggesting that the syringomycin-binding activity of the mutant is much lower than that of wild-type cells (Fig. 7). The decreased binding ability of $\operatorname{syr} 1-\Delta 1$ was restored when SYR1 was introduced by transformation with YCpN1 (SYR1) or YEp24 (SYR1) (Fig. 7). Supporting the possibility that membrane sterols are involved in the binding of syringomycin to the cell, the toxic effect of syringomycin for sensitive cells was relieved by the presence of low concentrations of sterols, such as cholesterol and ergosterol, added to the medium (data not shown).

\section{DISCUSSION}

$S Y R 1$ was cloned on the basis of its ability to complement the $\mathrm{Ca}^{2+}$-sensitive phenotype of syr 1 mutants. The cloned gene also suppressed syringomycin resistance when introduced into the mutant by a centromere-based vector. The gene had interesting phenotypic and molecular features. The mutant with the syr 1 allele was resistant to syringomycin, showed $\mathrm{Ca}^{2+}$-sensitive growth, and had a greatly increased $\mathrm{Ca}^{2+}$-uptake rate compared to wild-type cells (Takemoto et al., 1991). Since the syringomycin-resistant and $\mathrm{Ca}^{2+}$-sensitive phenotypes caused by the null mutation in $S Y R 1$ were very similar to those of syr1 mutants, the mutations possibly resulted in loss of function of the gene product. The sequence of SYR 1 was identical with the recently reported $S$. cerevisiae gene ERG3, which is suggested to code for C-5 sterol desaturase, the third terminal enzyme of ergosterol synthesis (Arthington $e$ t al., 1991). The ERG3 gene was cloned by complementation of the cycloheximide sensitivity of an $\operatorname{erg} 3$ mutant, which was originally identified as a mutation conferring nystatin resistance.

Western blot analyses using antibody directed against a LacZ-Syr1 fusion protein revealed a protein with an apparent size of $40 \mathrm{kDa}$ in the particulate fraction. The size of the protein detected agrees with that expected from the gene. The microsome is expected to be the location of terminal sterol biosynthetic enzymes such as C-5 sterol (a)

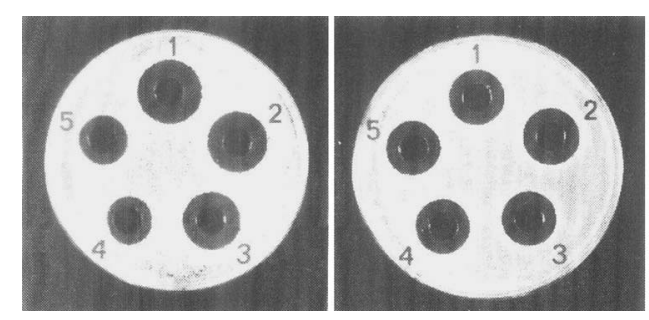

(c)

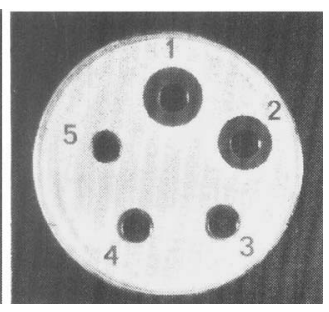

Fig. 7. Syringomycin binding activity of the syr1 mutant. The decrease in the amount of syringomycin in the fluid during incubation of cells in suspensions $\left(2 \times 10^{7}\right.$ cells in $200 \mu \mathrm{l}$ YPD medium) for $0,10,30$ and $60 \mathrm{~min}$ were measured. A $50 \mu \mathrm{l}$ sample of clarified fluid was taken, and the amount of toxin was determined semi-quantitatively by bioassay using syringomycin-sensitive $S$. cerevisiae as indicator. (a) YT1-1a (SYR1); (b) null mutant YT1-1b (syr1- 1 1); (c) YT1-1b harbouring YCpN1 (SYR1) plasmid. 1, Incubated without cells for $60 \mathrm{~min}$; $2-5$, incubated with cells for 0 (2), 10 (3), 30 (4) and $60 \mathrm{~min}(5)$. 
desaturase (Osumi et al., 1979). The predicted SYR1 $\mathrm{C}$-terminal four amino acids, Lys-Lys-X-X, are a retention signal for transmembrane endoplasmic reticulum proteins in mammalian cells (Jackson et al., 1990; Shin et al., 1991). However, clone 1, which contains an ORF lacking the C-terminal 43 amino acids of the Syr1 protein, complemented syr1, suggesting that the C-terminal portion is not essential when introduced on a multi-copy plasmid.

The availability of the gene responsible for susceptibility to syringomycin and its identification as the gene coding for an enzyme of ergosterol biosynthesis afforded an opportunity to correlate syringomycin action with sterol composition of the membrane. The syr 1 mutant cells lacked ergosterol and possibly C-5 desaturated sterols, as determined by the UV absorption spectrum of the nonsaponifiable lipid extract (Fig. 6). A similar relationship between membrane sterols and the resistance of mutants to polyene antibiotics, such as nystatin and amphotericin B, has been demonstrated (Lampen et al., 1962; Woods, 1971; Bard, 1972). Ergosterol has been identified as the cellular binding site for nystatin (Lampen et al., 1962). Binding experiments showed that the rate of syringomycin binding to syr 1 cells is lower than to wildtype cells (Fig. 7). These results suggest that membrane ergosterol facilitates the binding of syringomycin. The absence or severe reduction of ergosterol in the membrane results in resistance to the toxin. It is not clear, however, whether syringomycin binds directly to ergosterol, as does nystatin, or to another surface component dependent upon ergosterol biosynthesis. It was recently reported that sterol membrane composition affects the interaction of $S$. cerevisiae cells with iturin A, a lipopeptide antibiotic structurally unrelated to syringomycin (Latoud et al., 1990). The involvement of ergosterol could be the common mechanism for antifungal action of lipopeptides.

The sensitivity of the syr 1 strain to high $\mathrm{Ca}^{2+}$ concentrations, and the increased $\mathrm{Ca}^{2+}$ influx of the mutant, may be ascribed to lowered membrane ergosterol levels. Some sterol mutants of yeast have altered sensitivities to pulses (e.g. $10 \mathrm{~min}$ ) of hypertonic salt solutions (2 M), including $\mathrm{NaCl}$ and $\mathrm{CaCl}_{2}$, suggesting a change in ion permeability as a result of the alteration of the membrane sterol composition (Bard et al., 1978). Also, some sterol mutants become more sensitive to cycloheximide (Gaber et al., 1989; Arthington et al., 1991; Ashman et al., 1991). The syr1 mutant did not exhibit increased sensitivity to other ions tested, such as $\mathrm{KCl}$ and $\mathrm{MgCl}_{2}$, but the mutant was more sensitive to $\mathrm{NaCl}$ than wild-type cells (data not shown). Studies of $\mathrm{Ca}^{2+}$-sensitive mutants by several groups have shown that yeast has various mechanisms which allow it to grow with high $\mathrm{Ca}^{2+}$ concentrations. For example, vacuoles possess a potent $\mathrm{Ca}^{2+}$-uptake system driven by a $\mathrm{H}^{+}$-ATPase and serve as an intracellular store for $\mathrm{Ca}^{2+}$. Mutants of the subunit of the vacuolar $\mathrm{H}^{+}$-ATPase which are defective in vacuole acidification have sixfold higher cytosolic $\mathrm{Ca}^{2+}$ levels and were Pet $^{-}$(type IV cls mutants) (Ohya et al., 1991). These mutants exhibit increased $\mathrm{Ca}^{2+}$ uptake activity and their growth is $\mathrm{Ca}^{2+}$ sensitive. Although the syr 1 mutants exhibited similar phenotypes with respect to $\mathrm{Ca}^{2+}$ sen- sitivity and ${ }^{45} \mathrm{Ca}^{2+}$ uptake, the syr 1 mutants have normal levels of vacuolar ATPase activity and are not $\mathrm{Pet}^{-}$(data not shown).

Mutants (syr2 and syr4) that exhibited increased resistance to syringomycin without changes in $\mathrm{Ca}^{2+}$ sensitivity and had the wild-type sterol composition have been identified. Syringomycin bound to these mutants normally, but was unable to kill the cell. We are examining the defects of these mutants by cloning the genes that complement the phenotype due to the syr mutations. The structure of these genes may further provide information on the mechanism of syringomycin action in yeast.

\section{ACKNOWLEDGEMENTS}

We thank Y. Liu, E. Tsuchiya and T. Yamada for helpful discussion. The work was supported by National Science Foundation grant DCB 9003398 to J. Y.T.

\section{REFERENCES}

Arthington, B. A., Benett, L. G., Skatrud, P. L., Guynn, C. J., Barbuch, R. J., Ulbright, C. E. \& Bard, M. (1991). Cloning, disruption and sequence of the gene encoding yeast $\mathrm{C}-5$ sterol desaturase. Gene 102, 39-44.

Ashman, W. H., Barbuch, R. J., Ulbright, C. E., Jarnett, H. W. \& Bard, M. (1991). Cloning and disruption of the yeast C-8 sterol isomerase gene. Lipids 26, 628-632.

Bard, M. (1972). Biochemical and genetic aspects of nystatin resistance in Saccharomyces cerevisiae. J Bacteriol 111, 649-657.

Bard, M., Lees, N. D., Burrows, L. S. \& Kleinhans, F. W. (1978). Differences in crystal violet uptake and cation-induced death among yeast sterol mutants. J Bacteriol 135, 1146-1148.

Bidwai, A. P. \& Takemoto, J. Y. (1987). Bacterial phytotoxin, syringomycin, induces a protein kinase-mediated phosphorylation of red beet plasma membrane polypeptides. Proc Natl Acad Sci US A 84, 6755-6759.

Breivik, O. N. \& Owades, J. L. (1957). Spectrophotometric semimicro determination of ergosterol in yeast. Agric Food Chem 5, 360-363.

De Vay, J. E., Lukezic, F. L., Sinden, S. L., English, H. \& Coplin, D. L. (1968). A biocide produced by pathogenic isolates of Pseudomonas syringae and its possible role in the bacterial canker disease of peach. trees. Pbytopatbology 58, 95-101.

Fukuchi, N., Isogai, A., Yamashita, S., Suyama, K., Takemoto, J. Y. \& Suzuki, A. (1990). Structure of phytotoxin syringomycin produced by a sugar cane isolate of $P$ seudomonas syringae pv. syringae. Tetrabedron Lett 31, 1589-1592.

Gaber, R. F., Copple, D. M., Kennedy, B. K., Vida, M. \& Bard, M. (1989). 'The yeast gene ERG6 is required for normal membrane function but is not essential for biosynthesis of the cell-cyclesparking sterol. Mol Cell Biol 9, 3447-3456.

Ito, H., Fukuda, Y., Murata, K. \& Kimura, A. (1983). Transformation of intact yeast cells treated with alkali cations. J Bacteriol 153, 163-168.

Jackson, M. R., Nilsson, T. \& Peterson, P. A. (1990). Identification of a consensus motif for retention of transmembrane proteins in the endoplasmic reticulum. EMBO J 9, 3153-3161.

Lampen, J. O., Arnow, P. M., Borowska, Z. \& Laskin, A. I. (1962). Location and role of sterols at nystatin-binding sites. J Bacteriol $\mathbf{8 4}$, 1152-1160.

Latoud, C., Peypoux, F. \& Michel, G. (1990). Interaction of iturin A, 
a lipopeptide antibiotic, with Saccbaromyces cerevisiae cells: influence of the sterol membrane composition. Can J Microbiol 36, 384-389.

Liu, Y., Ishii, S., Tokai, M., Tsutsumi, H., Ohki, O., Akada, R., Tanaka, K., Tsuchiya, E., Fukui, S. \& Miyakawa, T. (1991). The Saccbaromyces cerevisiae genes (CMP1 and CMP2) encoding calmodulin-binding proteins homologous to the catalytic subunit of mammalian protein phosphatase 2B. Mol Gen Genet 227, 52-59.

Ohya, Y., Umemoto, N., Tanida, I., Ohta, A., lida, H. \& Anraku, Y. (1991). Calcium-sensitive $c l s$ mutants of Saccharomyces cerevisiae showing a $\mathrm{Pet}^{-}$phenotype are ascribable to defects of vacuolar membrane $\mathrm{H}^{+}$-ATPase activity. J Biol Chem 266, 13971-13977.

Osumi, T., Nishino, T. \& Katsuki, H. (1979). Studies on the $\Delta^{5}$ desaturation in ergosterol biosynthesis in yeast. $J$ Biochem $\mathbf{8 5}$, 819-826.

Rothstein, R. J. (1983). One-step gene disruption in yeast. Methods Enyymol 101, 202-211.

Sanger, F., Nicklen, S. \& Coulson, A. R. (1977). DNA sequencing with chain-terminating inhibitors. Proc Natl Acad Si US.A 74, 5463-5467.

Segre, A., Bachman, R. C., Ballio, A., Bossa, F., Grgurina, I., lacobellis, N. S., Pucci, P., Simmaco, M. \& Takemoto, J. Y. (1989). The structure of syringomycin A1, E and G. FEBS Lett 255, 27-31.

Shin, J., Dunbrack, R. L., Jr, Lee, S. \& Strominger, J. L. (1991). Signals for retention of transmembrane proteins in the endoplasmic reticulum studied with CD4 truncation mutants. Proc Natl Acad Sci US A 88, 1918-1922.

Sinden, S. L., De Vey, J. E. \& Backman, P. A. (1971). Properties of syringomycin, a wide spectrum antibiotic and phytotoxin produced by $P$ seudomonas syringae, and its role in the bacterial canker disease of peach trees. Physiol Plant Patbol 1, 199-213.

Takemoto, J. Y., Zhang, L., Taguchi, N., Tachikawa, T. \& Miyakawa, T. (1991). Mechanism of action of the phytotoxin syringomycin: a resistant mutant of Saccharomyces cerevisiae reveals an involvement of $\mathrm{Ca}^{2+}$ transport. J Gen Microbiol 137, 653-659.

Tanaka, K., Matsumoto, K. \& Toh-E, A. (1989). IR A1, an inhibitory regulator of the $\mathrm{R} A S$-cyclic AMP pathway in Saccharomyces cerevisiae. Mol Cell Biol 9, 757-768.

Woods, R. A. (1971). Nystatin-resistant mutants of yeast: alterations in sterol content. $J$ Bacteriol 108, 69-73.

Zhang, L. \& Takemoto, J. Y. (1986). Mechanism of action of Pseudomonas syringae phytotoxin, syringomycin. Interaction with the plasma membrane of wild-type and respiratory-deficient strains of Saccharomyces cerevisiae. Biochim Biopbys Acta 861, 201-204.

Zhang, L. \& Takemoto, J. Y. (1987). Syringomycin stimulation of potassium efflux by yeast cells. Biochim Biophys Acta 987, 171-175.

Received 20 April 1993; accepted 24 September 1993. 